\title{
Experimental encephalitis caused by Taenia crassiceps cysticerci in mice
}

\author{
Encefalite experimental causada por cisticercos de Taenia crassiceps em camundongos \\ Hidelberto Matos-Silva',3, Bruno Pereira Reciputti', Élbio Cândido De Paula², André Luiz Oliveira', Vânia \\ Beatriz Lopes Moura ${ }^{1}$, Marina Clare Vinaud ${ }^{1}$, Milton Adriano Pelli Oliveira ${ }^{1}$, Ruy de Souza Lino-Júnior ${ }^{1}$
}

\begin{abstract}
Objectives: To present the experimental model of neurocysticercosis (NCC) caused by Taenia crassiceps cysticerci, to describe the inflammatory process, susceptibility, or resistance of BALB/c and C57BL/6 mice to this infection, and to describe the host-parasite relationship. Methods: The animals were intracranially inoculated with initial stage T. crassiceps cysticerci. They were euthanized at 7, 30, 60, and 90 days after the inoculation. Their encephala were removed for the histopathologic analysis, classification of the parasites, and inflammatory lesions. Results: Experimental NCC was observed on both mice lineages. BALB/c mice presented inflammatory lesions with greater intensity, inducing necrosis on late stage parasites, and with an acute inflammation pattern, while C57BL/6 mice showed greater capability on provoking early necrosis in the cysticerci, which showed a chronic inflammation pattern. Conclusions: This experimental model induced NCC on mice with characteristic inflammation and lesions. C57BL/6 mice were able to induce precocious necrosis of the parasites presenting inflammatory lesions with lower intensity.
\end{abstract}

Key words: neurocysticercosis, Taenia crassiceps, BALB/c, C57BL/6.

\section{RESUMO}

Objetivos: Apresentar o modelo experimental de neurocisticercose (NCC) com cisticercos de Taenia crassiceps, descrever a inflamação, suscetibilidade e resistência em camundongos BALB/c e C57BL/6, caracterizando melhor a relação parasito-hospedeiro. Métodos: Os animais foram inoculados intracranialmente com cisticercos de T. crassiceps em estádio inicial e eutanasiados aos 7, 30, 60 e 90 dias após a infecção. Retiraram-se os encéfalos para análise histopatológica, classificação dos parasitos e lesões inflamatórias. Resultados: Foi possível induzir NCC nas duas linhagens de camundongos utilizados como modelo experimental. Os animais BALB/c apresentaram lesões inflamatórias mais intensas do que os camundongos C57BL/6 e induziram nos parasitos necrose na fase tardia com padrão inflamatório agudo. Os C57BL/6 mostraram-se mais hábeis em provocar necrose precocemente nos cisticercos, mas com padrão inflamatório crônico. Conclusões: Este modelo experimental induziu NCC nos animais com inflamações e lesões. Os camundongos C57BL/6 foram hábeis em induzir precocemente necrose nos parasitos, apresentando lesões inflamatórias com menor intensidade.

Palavras-Chave: neurocisticercose, Taenia crassiceps, BALB/c, C57BL/6.

Neurocysticercosis (NCC) is one of the main parasitary diseases of the central nervous system (CNS) caused by Taenia solium cysticerci $^{1}$, which are responsible for significant morbidity associated with seizures and hydrocephaly ${ }^{2,3}$.

It is considered an emerging disease in most developed countries especially due to the increase in the number of immigrants from endemic areas and to a few documented cases of local transmission ${ }^{3,4}$. According to a recent study, with patients from a neurologic clinic in Texas, USA, 53\% of the hospitalizations occurred due to NCC, and epilepsy was the main clinical symptom. From these NCC patients, 93\% were Hispanic immigrants 4 . As it presents great clinic diversity, NCC has been the target of several clinic, serum epidemiologic and histopathologic studies ${ }^{5}$, which aim at understanding the mechanisms involved in the immune and inflammatory responses ${ }^{6}$.

The use of experimental models to the comprehension of the host-parasite relationship has become an excellent tool to study the human cysticercosis in several organs, including its severe

${ }^{1}$ Instituto de Patologia Tropical e Saúde Pública, Universidade Federal de Goiás, Goiânia GO, Brazil;

${ }^{2}$ Faculdade de Medicina, Universidade Federal de Goiás, Goiânia GO, Brazil;

${ }^{3}$ Faculdade de Medicina, Centro Universitário UNIRG, Gurupi TO, Brazil.

Correspondence: Marina Clare Vinaud; Instituto de Patologia Tropical e Saúde Pública da Universidade Federal de Goiás; Rua 235 s/n / Qd. 62 / Lt. ar 1 / ST. Universitário; 74605-050 Goiânia GO - Brasil; E-mail:mvinaud@yahoo.com.br

Support: National Counsel of Technological and Scientific Development (CNPq) and Fundação de Amparo à Pesquisa of Universidade Federal de Goiás (FUNAPE).

Conflict of interest: There is no conflict of interest to declare.

Received 19 October 2011; Accepted 01 November 2011 
form, the $\mathrm{NCC}^{6}$. The parasite most used in those cysticercosis experimental models is Taenia crassiceps as it presents rapid developing cycle, easy maintenance, and antigenic similarity to T. solium ${ }^{7,8}$. The intraperitoneal model ${ }^{7}$ is the most diffused one as it is useful on the evaluation of genetic factors involved in the resistance or susceptibility of hosts and especially of the immunological mechanisms ${ }^{9}$. The most described experimental model in literature to NCC studies is the one reported by Cardona et al. ${ }^{10}$, who used Mesocestoides corti ${ }^{10,11}$.

According to the literature, BALB/c mice are less resistant than $\mathrm{C} 57 \mathrm{BL} / 6$ to the experimental intraperitoneal infection with $T$. crassiceps cysticerci ${ }^{9}$. While in the most severe form of the disease, NCC, there are few reports on the inflammatory and immunological mechanisms from the host as well as on the evasion mechanisms used by the parasite as to survive in this hostile environment. It is known that, in the beginning of the intraperitoneal infection, there is a type 1 cytokine that cause an inflammatory response, which controls the parasite's growth. However, this response rapidly changes to type 2 or even to a mixed type 1 /type 2 profile of cytokines, which is permissive to the parasite's growth. The type 2 immune response results in a derestrict growth of the parasite that may lead to the death of the animal in experimental cases, demonstrating little or no immunologic resistance to the parasitary growth ${ }^{12,13}$.

The objectives of this study were to develop an experimental model that could induce NCC in mice by using T. crassiceps cysticerci, to observe the differences in the inflammatory reaction and consequent lesions in BALB/c and C57BL/6 mice, and to determine their susceptibility or resistance to the infection.

\section{METHODS}

\section{Maintenance of the parasite}

The biological cycle of T. crassiceps (ORF strain) has been maintained in the animal facility of the Tropical Pathology and Public Health Institute from the Federal University of Goias (IPTSP/ UFG), since 2002. Ten initial phase cysticerci were inoculated in the intraperitoneal cavity from 8 to 12 weeks-old female BALB/c mice, where they were multiplied by budding. Approximately 90 days after inoculation, the animals were euthanized and necropsied, and the initial stage cysticerci ${ }^{14}$ was removed and washed several times with sterile saline solution and inoculated in the peritoneal cavity of noninfected BALB/c female mice ${ }^{15}$.

\section{Animals}

Matrices from conventional female BALB/c and C57BL/6 mice were maintained in the animal facility of the IPTSP/UFG. For this study, we used animals from 8 to 12 weeks-old and with 20 to $30 \mathrm{~g}$. These animals were intracranially inoculated with three to five initial stage cysticerci. The animals were divided into four groups, containing five animals for each experimental day $(7,30,60$, and 90 days after the inoculation) named as: Group 1 - BALB/c mice infected with cysticerci; Group 2 - BALB/c mice inoculated with sterile saline solution; Group 3 - C57BL/6 mice infected with cysticerci; and Group 4 - C57BL/6 mice inoculated with sterile saline solution.

The ethical principles for animal experimentation professed by the Brazilian Society of Laboratory Animal Sciences (SBCAL) were followed. This study was authorized by the Ethics Research Committee of the Federal University of Goiás (CoEp/UFG), registration number 034/09.

\section{Experimental infection}

The animals were weighted and anesthetized previously to the inoculation. The anesthetics consisted of a solution of Ketamine $(100 \mathrm{mg} / \mathrm{mL})$ and Xilazine $(20 \mathrm{mg} / \mathrm{mL})$ in the proportion of $0.1 \mathrm{~mL} / 10 \mathrm{~g}^{16,17}$. After the trichotomy of the head superior portion and the antisepsis with topic iodine, a longitudinal and median incision was made on the skin of the skull with a scalpel. The trepanation orifice was performed with a drill (44.5x2 mm) moved by a micromotor (LB100-Beltec) ${ }^{18}$ in the topography of the right parietal bone at $3 \mathrm{~mm}$, from the median line (sagittal suture), and at $3 \mathrm{~mm}$ posterior to the coronal suture and with $4 \mathrm{~mm}$ of depth. The infected animals were intracranially inoculated with cysticerci and afterwards the trepanation orifice was closed with sterile dental alginate and the incision was sutured.

\section{Removal of the encephala}

At 7, 30, 60, and 90 days after the inoculation (DAI), the animals were intraperitoneally anesthetized with $0.1 \mathrm{~mL} / 10 \mathrm{~g}$ of the Xilazine $2 \%$ and Ketamine $10 \%$ solution. Afterwards, the animals were euthanized by cervical dislocation and had their encephala removed to posterior analysis.

\section{Histopathological analysis}

The histopathological analysis was performed with fragments of the encephala. They were fixed with 3.4\% buffered formalin; dehydrated with alcohols; clarified with Xylol; and then blocked into paraffin and sectioned into 5 micrometer sections; stained with hematoxylin and eosin (HE) and other histochemical techniques when necessary, such as picrossirius, to fibrosis identification, periodic acid of Schiff (PAS), to glycidic radicals identification, von Kossa, to calcium salts deposits identification, and Congo red to amyloidosis identification ${ }^{19}$.

\section{Quantification of the cysticerci and their} classification into development stages

Through microscopic analysis, the anatomical localization of the cysticerci was described as well as its classification, according to its development stage into initial, larval, and final ${ }^{14}$.

\section{General pathologic processes analysis}

The general pathologic processes were analyzed inside the parasite, in the host-parasite interface, and in the host tissue considering the presence of an inflammatory process (parenchyma, meninges, and blood vessels) and its cellular profile, edema, hyperemia, calcification, fibrosis, glycidic radical deposits, 
gliosis, and microgliosis. The pathologic processes described were classified into a semi-quantitative way according to the following criteria: absent; discrete with up to $25 \%$ of the compromised area; moderate from 26 to $50 \%$ of the compromised area and accentuated above $50 \%$ of the compromised area ${ }^{19}$.

\section{Statistical analysis}

The statistical analysis was performed by using the Sigma Stat 3.5 program. All variables were tested as to their normal distribution and homogenous variation. As they presented nonnormal distribution, the variables were analyzed by the nonparametric Mann-Whitney's test. The differences were considered significant when $\mathrm{p}<0.05$.

\section{RESULTS}

This study described the development of an experimental model to NCC studies involving two mice lineages. These

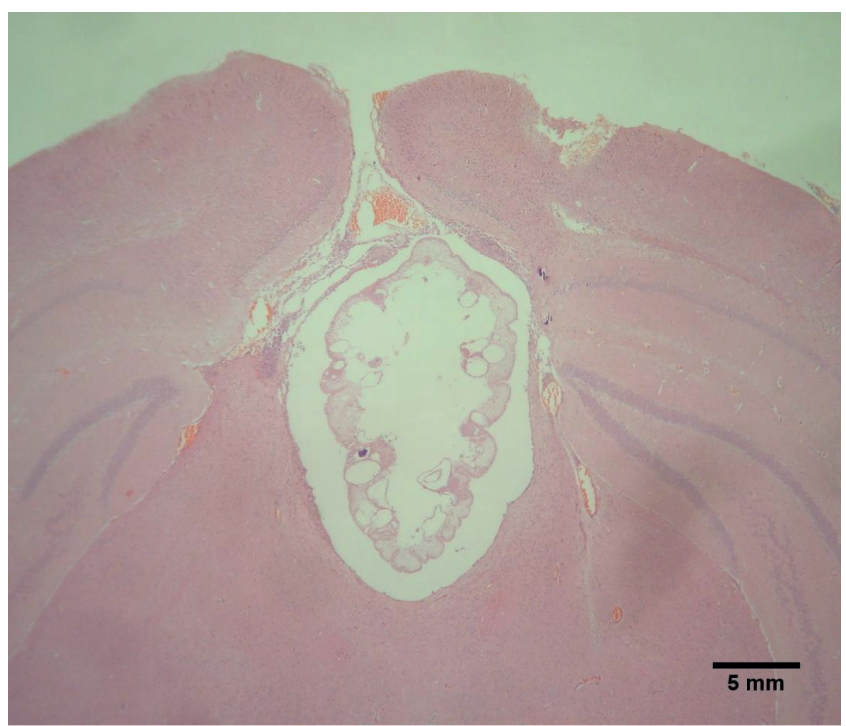

Fig 1. Mesoscopic image of an encephalum from BALB/c mouse at 60 DAI with a larval stage cysticerci inside the third dorsal ventricle, hyperemia in the adjacent blood vessels, and inflammatory infiltration (HE, scale $=5 \mathrm{~mm}$ ). lineages were compared as to their susceptibility or resistance to infection by $T$. crassiceps cysticerci, and also as to the inflammatory process that each one developed throughout 90 days of intracranial infection.

All infected animals presented cysticerci located in the brain ventricles (lateral and dorsal) provoking inflammation, expansion to this cavity and, consequently, deviation of the median line. Those effects were observed with greater intensity in BALB/c mice (Fig 1 and 2, Tables 1 and 2).

On both lineages, a decrease in the consistency and hypotrophy of the encephala parenchyma was observed. At $7 \mathrm{DAI}$, the cysticerci found were classified into the initial development stage on both lineages, while at 30 DAI larval stage cysticerci were found only in C57BL/6 mice (Fig 3A to D). Final stage cysticerci were found more precociously in C57BL/6 mice, at 60 DAI (Fig 3E and F) than in BALB/c mice, at 90 DAI (Fig 3G, Table 1). Also, the inflammatory infiltration observed in BALB/c mice being more intense than the one observed in C57BL/6 mice (Fig $3 \mathrm{H}$, Table 1). Final stage cysticerci also presented discrete areas of fibrosis, decreased glycidic material deposit, and necrosis.

When analyzing the host-parasite interface from infected BALB/c mice, it was possible to observe an intra-parenchymatous inflammatory infiltration with predominance of polymorphonuclear cells. In C57BL/6 mice, the inflammatory cells predominance was of mononuclear cells. At 30DAI the perivasculitis was significantly greater in BALB/c mice. Meanwhile, the hyperemia was greater in $\mathrm{C} 57 \mathrm{BL} / 6$ mice throughout the experimental period (Table 2). In animals from the Control Group, which were inoculated with sterile saline solution, only a discrete hyperemia and edema were observed at seven DAI, and it was self-limited and was not observed at other experimental days.

When analyzing the reactions on the tissues from the host in some regions, such as the parenchyma near the brain ventricles, it was possible to observe that BALB/c mice presented more intense ependymitis, edema, and meningitis than what was observed in C57BL/6 mice. Only the hyperemia was more intense in C57BL/6 mice (Table 3). At 60 and 90 DAI, all infected animals presented areas of fibrosis in the ependyma region close to the parasites (Table 3).
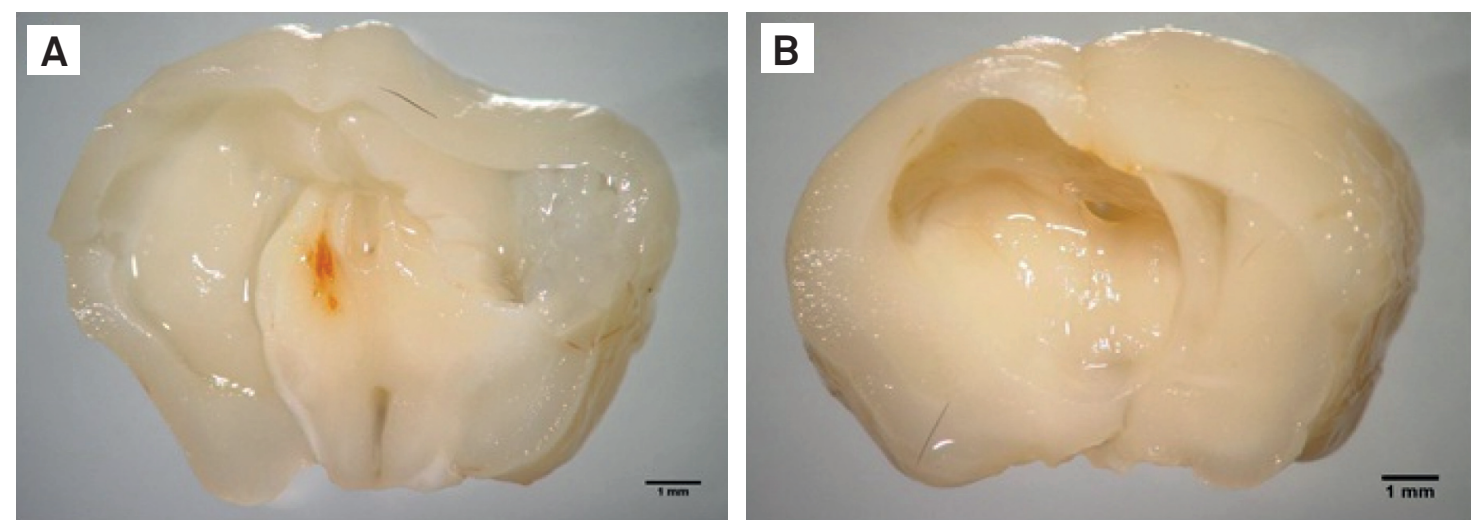

Fig 2. Mesosocopic image from encephala of BALB/c (A) and C57BL/6 (B) mice in a coronal section, presenting a cysticercus that induced ventriculomegaly and deviation of the median line (scale $=1 \mathrm{~mm}$ ). 
Table 1. Inflammatory reaction in parasites found in BALB/c and C57BL/6 mice experimentally infected with T. crassiceps cysticerci.

\begin{tabular}{|c|c|c|c|c|c|c|c|c|}
\hline & \multicolumn{4}{|c|}{ BALB/c } & \multicolumn{4}{|c|}{ C57BL/6 } \\
\hline & $7 \mathrm{DAl}$ & $30 \mathrm{DAl}$ & $60 \mathrm{DAl}$ & $90 \mathrm{DAl}$ & $7 \mathrm{DAl}$ & $30 \mathrm{DAl}$ & $60 \mathrm{DAI}$ & $90 \mathrm{DAl}$ \\
\hline Development stage & $\mathrm{INI}$ & $\mathrm{INI}$ & LAR & FIN & $\mathrm{INI}$ & LAR & FIN & FIN \\
\hline Location & LV & LV & LV/ $3^{\text {rd }} \mathrm{DV}$ & LV & LV & LV & LV & LV \\
\hline I.I. (PMN/MN) & - & - & ++ & +++ & + & + & ++ & ++ \\
\hline Calcification & - & - & - & - & - & - & - & - \\
\hline Fibrosis & - & - & - & + & - & - & - & + \\
\hline Glycidic deposit & - & - & +++ & + & + & +++ & + & + \\
\hline
\end{tabular}

DAI: days after the inoculation; INI: initial; LAR: Larval; FIN: final; LV: lateral ventricle; DV: dorsal ventricle; PMN: polymorphonuclear cells; MN: mononuclear cells; I.I.: inflammatory infiltration; + : discrete; ++ : moderate; +++ : accentuated; $n=5$ per each experimental day.

Table 2. Pathological processes found in the host-parasite interface in BALB/c and C57BL/6 mice experimentally infected with $T$. crassiceps cysticerci.

\begin{tabular}{|c|c|c|c|c|c|c|c|c|}
\hline & \multicolumn{4}{|c|}{$\mathrm{BALB} / \mathrm{c}$} & \multicolumn{4}{|c|}{ C57BL/6 } \\
\hline & $7 \mathrm{DAl}$ & $30 \mathrm{DAl}$ & $60 \mathrm{DAl}$ & $90 \mathrm{DAl}$ & $7 \mathrm{DAl}$ & $30 \mathrm{DAl}$ & $60 \mathrm{DAl}$ & $90 \mathrm{DAl}$ \\
\hline Ventriculomegaly & + & ++ & +++ & +++ & + & ++ & ++ & +++ \\
\hline Hyperemia & + & + & ++ & + & + & ++ & ++ & ++ \\
\hline Perivasculitis & + & $++^{*}$ & ++ & +++ & + & $+^{*}$ & ++ & ++ \\
\hline I.I. - PMN & + & ++ & ++ & +++ & + & + & + & + \\
\hline I.I. $-\mathrm{MN}$ & + & + & ++ & ++ & + & ++ & ++ & ++ \\
\hline
\end{tabular}

DAI: days after the inoculation;I.I.: inflammatory infiltration; PMN: polymorphonuclear cells; MN: mononuclear cells; +: discrete; ++:moderate; +++:accentuated; $n=5$ per each experimental day. ${ }^{*}<0.05$.

Table 3. Pathological processes found in the host tissue from BALB/c and C57BL/6 mice experimentally infected with T. crassiceps cysticerci.

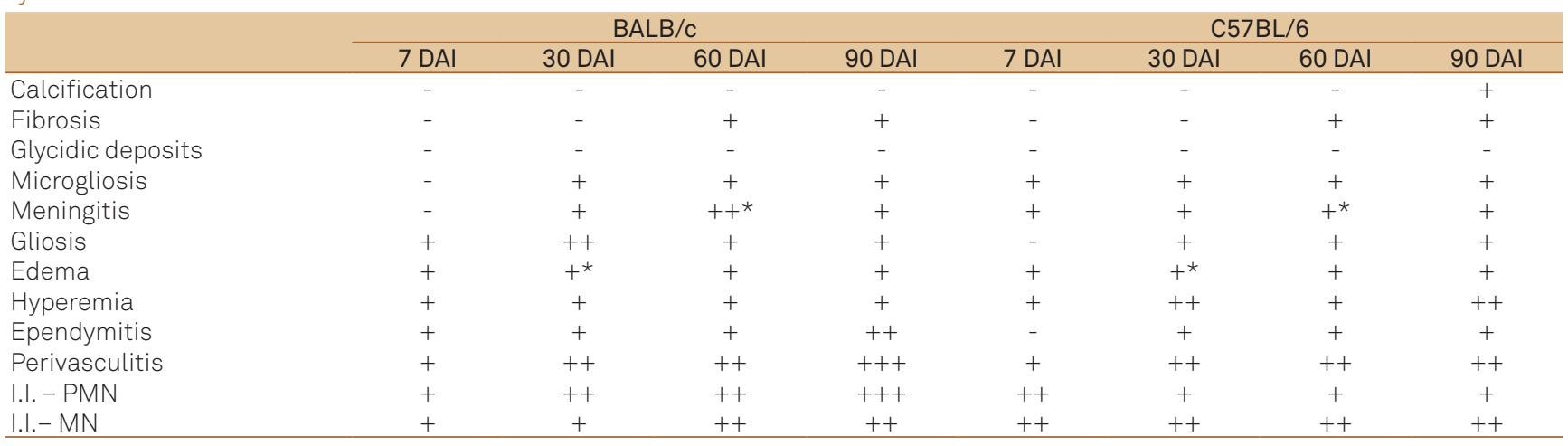

DAl:days after the inoculation;I.I.:inflammatory infiltration; PMN: polymorphonuclear cells; MN: mononuclear cells; +:discrete; ++:moderate;+++:accentuated; $n=5$ per each experimental day. ${ }^{*} p<0.05$.

Microgliosis was observed at 7 DAI in C57BL/6 mice, while in BALB/c mice it was observed only at $30 \mathrm{DAI}$. Also, in the first ones a more intense gliosis in relation to the latter was observed. Discrete areas of calcification were found in the brain parenchyma in the region of the caudal putamen in infected C57BL/6 mice at 90 DAI (Table 3).

\section{DISCUSSION}

Both lineages of mice used in this study could induce necrosis on the parasites at 90 DAI. However, in C57BL/6 mice, this destruction occurred in a more efficient manner since 60 DAI. In spite of that, the inflammation composed mainly by polymorphonuclear cells associated with edema, perivasculitis, and meningitis in BALB/c mice was significantly greater than what was observed in the C57BL/6 ones during the experimental period. Fragoso et al. ${ }^{9}$, when inoculating BALB/c mice via intraperitoneal with T. crassiceps cysticerci, observed that they presented a greater parasitary burden than C57BL/6 mice and considered the first susceptible to T. crassiceps cysticerci infection. We believe that this lower capability to induce necrosis on the parasites from BALB/c mice may have occurred due to the predominance of polymorphonuclear cells in the inflammatory infiltration throughout the infection. On the other hand, C57BL/6 mice already presented mononuclear cells in the inflammatory infiltration at 60 DAI. Probably due to this difference, the intensity in the ventriculomegaly, the destruction of the adjacent parenchyma, the deviation of the median line, and the gliosis have been greater in $\mathrm{BALB} / \mathrm{c}$ mice.

In the initial phase of the inflammation (7 and $30 \mathrm{DAI}$ ), $\mathrm{BALB} / \mathrm{c}$ mice presented lesions such as gliosis in the parenchyma adjacent to the lateral ventricles. This may have occurred due to the triggered type of immune response (cellular or humoral), the control of the parasitary growth, the ventricle expansion or the presence of circulating antibodies. Reports from the literature describe that it is not necessary the presence of intraventricular cysts for the development of lesions, such as ventriculomegaly, and even the obstruction of the cerebrospinal fluid flow as the presence of circulating 
antigens from the parasite are enough to cause those reactions, even without the inflammatory reaction in the cavity ${ }^{20-22}$. The activation and proliferation of the microglia, which is named microgliosis, were discretely higher in C57BL/6 mice throughout the experiment. These data are in accordance to the cellular profile of response, type 1 , observed in these animals ${ }^{23}$. These cells are the main guard ones of the CNS. Once there is a lesion in the encephalic tissue, the microglia goes through an activation process in which there is the modification of its morphology, surface phenotype characteristics, hypertrophy, increase in the expression of complement receptors such as CR3, increase in the expression of molecules from the main histocompatibility complex (MHC), transforming the cell into one more capable of defending and stimulating the regeneration of the destroyed nervous tissue ${ }^{24,25}$.

In the late phase of the inflammation (60 and 90 DAI), in spite of $\mathrm{BALB} / \mathrm{c}$ mice presented a greater intensity in the inflammatory infiltration than C57BL/6 ones, the latter were more capable of containing the growth of the cysticerci and of inducing their death. The inflammatory infiltration with the predominance of polymorphonuclear cells was a remarkable characteristic of the infected $\mathrm{BALB} / \mathrm{c}$ mice, while in C57BL/6 mice the predominance was of mononuclear cells. Fragoso et al..$^{23}$, when evaluating the susceptibility and resistance of those both lineages against $T$. crassiceps cysticerci intraperitoneal infections, reported that C57BL/6 mice presented lower parasitary growth and development of lesions and a predominance of type $1 \mathrm{immune}$ response. On the other hand, BALB/c mice presented a predominance of type 2 immune response which is humoral ${ }^{26,27}$. All infected animals from both lineages from this study presented discrete areas of fibrosis, which demonstrates tissue destruction due to the action of the parasite and the host inflammatory response aiming at eliminating the pathogen and the finalization of the inflammatory process. In the animals from the Control Group, we also observed discrete edema and hyperemia in the initial days of the experiment. These reactions were not observed in the subsequent days of the experiment and we believe that they occurred due to the sterile saline inoculation procedure.

The dystrophic calcification areas observed in infected C57BL/6 mice at $90 \mathrm{DAI}$ are in accordance to the findings from other authors ${ }^{19,28}$. According to the human NCC classification proposed by Cuetter et al. ${ }^{28}$, in the intraventricular active form there may be an obstruction of the cerebrospinal fluid flow and hypodensic areas in the nuclear magnetic resonance examination, while in the inactive form there is the late hydrocephaly without adjacent calcification areas. Probably the strong type 1 immune response, which is characteristic of the C57BL $/ 6$ mice $^{6,9}$, may be responsible for the injuries to the adjacent tissues right at the initial phase of the infection, resulting in the contention of the parasitary growth, its death and calcification.

The experimental model presented in this study, which used T. crassiceps cysticerci, may become a reproducible method for human NCC studies because the parasite caused a dynamic inflammatory response from the host, which evolved throughout

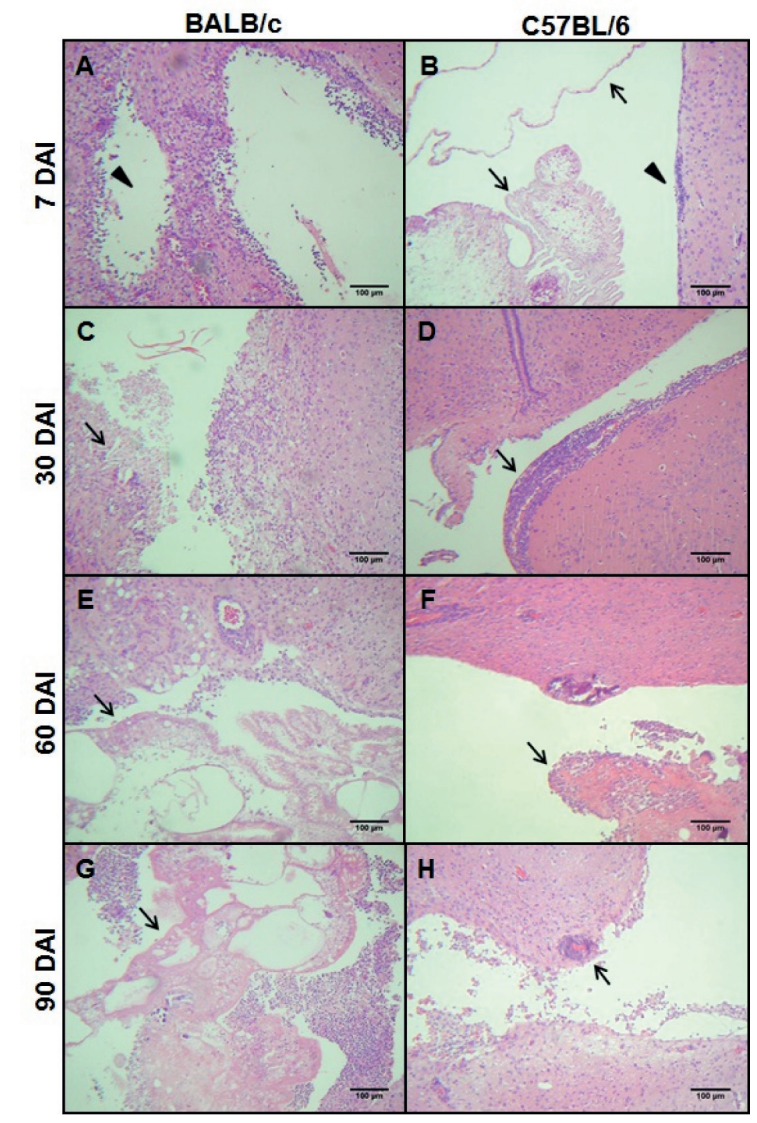

Fig 3. Photomicrography of encephala from BALB/c and C57BL/ 6 mice. At 7 days after the inoculation (DAI), it was possible to observe: (A) BALB/c mice with a small area of necrosis near the lateral ventricle (arrow) and discrete inflammatory infiltration; (B) C57BL/6 mice with initial and larval (arrows) stage cysticerci inside the lateral ventricle and discrete ependymitis (arrow head). At 30 DAl: (C) BALB/c mice with destruction of the ventricular wall, presence of cholesterol crystals (arrow), and discrete inflammatory infiltration; (D) C57BL/ 6 mice with discrete meningitis (arrow). At 60 DAl: (E) BALB/c mice presenting larval stage cysticercus (arrow) inside the lateral ventricle; (F) C57BL/6 mice with final stage cysticercus (arrow) and accentuated inflammatory infiltration surrounding the parasite. At 90 DAl: (G) BALB/c mice with final stage cysticercus (arrow) and accentuated inflammatory infiltration surrounding the parasite and $(\mathrm{H}) \mathrm{C} 57 \mathrm{BL} / 6$ mice presenting moderate vasculitis (arrow) (HE, scale=100 $\mu \mathrm{m})$.

the experimental days and also because the Control Group presented minor lesions, such as discrete hyperemia and edema, due to the inoculation procedures only in the initial days of the experiment. T. crassiceps cysticerci present other advantages such as its rapid development cycle, facilities in maintenance, and antigenic similarities to T. solium cysticerci ${ }^{7}$.

The previously described NCC model in the literature uses Mesocestoides cort $i^{10,11}$, which are not even from the Taenia genus and do not present the cysticercus evolutive form, they only present the cysticercoid and tetrathyridium forms. Also, the $M$. corti experimental model presents another drawback as this parasite can proliferate and invade brain tissue $e^{11,17}$, which was not observed in the T. crassiceps model. The main studies related to the immune and inflammatory responses in experimental 
cysticercosis caused by $T$. crassiceps report their findings through the intraperitoneal model ${ }^{9}$. The model proposed in this study may reproduce NCC and the inoculation of the parasite could occur in several areas of the encephalon such as the hippocampus, which may be correlated to seizures that represent the most common human clinic form of NCC.

Therefore, it was possible to induce NCC in both mice lineages proving it to be a good experimental model. The lesions and alterations observed were ventriculomegaly, perivasculitis, meningitis, microgliosis, and inflammation. The observation of the pathological processes in the encephala removed from the infected animals it is possible to conclude that BALB/c mice are less efficient in inducing precocious necrosis of the parasite and they present an acute inflammatory profile. While the C57BL/6 mice are more capable of provoking the parasite's death, they have a chronic inflammatory profile, less intensity of the alterations and lesions and therefore are considered more resistant to T. crassiceps cysticerci infection.

\section{References}

1. Agapejev S. Aspectos clínico-epidemiológicos da neurocisticercose no Brasil: Análise crítica. Arq Neuropsiquiatr 2003;61:822-828.

2. White Jr AC. Neurocysticercosis: updates on epidemiology, pathogenesis, diagnosis, and management. Ann Rev Med 2000;51: 187-206.

3. Prasad KN, Prasad A, Gupta RK, et al. Neurocysticercosis in Patients with Active Epilepsy From a Pig Farming Community. Trans R Soc Trop Med Hyg 2009;103:144-150.

4. White Jr AC, Serpa JA, Graviss EA, Kass JS. Neurocysticercosis in Houston, Texas an update. Medicine 2011;90:81-86.

5. Del Brutto OH, Santibanez R, Idrovo L, et al. Epilepsy and neurocysticercosis in Atahualpa: a door-to-door survey in rural coastal Ecuador. Epilepsia 2005;46:583-587.

6. Terrazas IL. The Complex role of pro- and anti-inflammatory cytokines in cysticercosis: immunological lessons from experimental and natural hosts. Curr Top Med Chem 2008;8:383-392.

7. Sciutto E, Fragoso G, Trueba L, et al. Cysticercosis vaccine: cross rotecting immunity with $T$. solium antigens against experimental murine T. crassiceps cysticercosis. Parasite Immunol 1990;12: 687-696.

8. Sciutto E, Chavarria A, Fragoso G, Fleury A, Larralde C. The immune response in Taenia solium cysticercosis: protection and injury. Parasite Immunol 2007;29:621-636

9. Fragoso G, Lamoyi E, Mellor A, Lomeli C, Hernandez M, Sciutto E. Increased resistance to Taenia crassiceps murine cysticercosis in Qa-2 transgenic mice. Infec Immunity 1998;66:760-764.

10. Cardona AE, Restrepo BI, Jaramillo JM, Teale JM. Development of an animal model for neurocysticercosis: immune response in the central nervous system is characterized by a predominance of gamma delta $T$ cells. J Immunol 1999;162:995-1002.

11. AlvarezJI, Mishra BB, Gundra UM, Mishra PK, TealeJM. Mesocestoides corti intracranial infection as a murine model for neurocysticercosis. Parasitology 2010;137:359-372.

12. Toenjes SA, Spolski RJ, Mooney KA, Kuhn RE. The systemic immune response of BALB/c mice infected with larval Taenia crassiceps is a mixed Th1/Th2-type response. Parasitology 1999;118:623-633.

13. Kuhn RE, AldridgeJR, Johnson EC. Cpg stimulates protective immunity in Balb/Cj mice infected with Larval Taenia crassiceps. J. Parasitol 2010;96:920-928.

14. Vinaud MC, Ferreira CS, Lino Jr RS, Bezerra JCB. Taenia cracisseps: Energetic and respiratory metabolism from cysticerci exposed to praziquantel and albendazole in vitro. Exp Parasitol 2008;120: 221-226.
15. Vaz AJC, Nunes M, Piazza RM, et al. Immunoblot with cerebrospinal fluid from patients with neurocysticercosis using antigen from cysticerci of Taenia solium and Taenia crassiceps. Am J Trop Med Hyg 1997;57:354-357.

16. CETEA-UFMG 2008. Protocolos Anestésicos. [Internet]. [cited 2011 Aug 24]. Available at www.ufmg.br/bioetica/cetea/index2. php?option=com_content\&do_pdf=1\&id=22.

17. Alvarez JI, Rivera J, Teale JM. Differential release and phagocytosis of tegument glycoconjugates in neurocysticercosis: implications for immune evasion strategies. PLoS Neglected Trop Dis 2008;2:e218.

18. Michailowsky C. Experimental tumors of the central nervous system: standardisation of a model in rats using the $9 \mathrm{~L}$ glioma cells. Ara Neuropsiquiatr 2003;61:234-240.

19. Lino-Jr RS, Ribeiro PM, Antonelli EJ, et al. Características evolutivas do Cysticercus cellulosae no encéfalo e no coração. Rev Soc Bras Med Trop 2002;35:617-622.

20. Garcia HH, Gonzalez AE, Gilman RH. Cysticercosis Working Group in Peru. Circulating parasite antigen in patients with hydrocephalus secondary to neurocysticercosis. Am J Trop Med Hyg 2002;66: 427-430.

21. Agapejev S, Pouza AFP, Bazan R, Faleiros ATS. Aspectos clínicos e evolutivos da hidrocefalia na neurocisticercose. Arq Neuropsiquiatr 2007:65:674-680.

22. Gasparetto EL, Eiras de Araújo AL, Rodrigues RS, et al. Migrating intraventricular cysticercosis.Arq Neuropsiquiatr 2008;66:111-113.

23. Fragoso G, Meneses G, Sciutto E, Fleury A, Larralde C. Preferential growth of Taenia crassiceps Cysticerci in female mice holds across several laboratory mice strains and parasite lines. I Parasitol 2008;94:551-553.

24. Sreit JW, Sharon AW, Pennel AN. Reactive microgliosis. Progress Neurobiol 1999;57:563-581.

25. Ransohoff RM. Microgliosis: the questions shape the answers. Nature Neurosc 2007;10:1507-1509.

26. Larralde C, Morales J, Terrazas I, Govezensky T, Romano MC. Sex hormone changes induced by the parasite lead to feminization of the male host in murine Taenia crassiceps cysticercosis. J Steroid Biochem Molec Biol 1995;52:575-580.

27. Villa OF, Kuhn RE. Mice infected with the larvae of Taenia crassiceps exhibit a Th2-like immune response with concomitant anergy and downregulation of Th1-associated phenomena. Parasitology 1996:112:561-570.

28. Cuetter AC, Garcia-Bodadilha, Guerra JLG, Martinez FM, Kaim B Neurocysticercosis: focus on intraventricular disease. Clin Infec Dis 1997;24:157-164 